\title{
N-Acetylcysteine and Sulodexide Reduce the Prothrombotic Effect of Uremic Serum on the Venous Endothelial Cells
}

\author{
Patrycja Sosinska-Zawierucha Beata Mackowiak Andrzej Breborowicz \\ Department of Pathophysiology, Poznan University of Medical Sciences, Poznan, Poland
}

\section{Keywords}

Uremia $\cdot$ Venous endothelium $\cdot \mathrm{N}$-acetylcysteine $\cdot$ Sulodexide

\begin{abstract}
Background/Aims: Thromboembolic episodes are a frequent problem in end stage renal failure patients. The pathomechanism of the disorder is complex, including bioincompatibility of renal replacement therapy, endothelial dysfunction, increased blood level of procoagulant factors and uremic toxins. We studied changes in the functional properties of venous endothelial cells (VEC) in the presence of uremic serum and evaluated their possible modulation by $\mathrm{N}$-acetylcysteine (NAC) or sulodexide (SUL). Methods: Serum samples from 12 uremic patients treated with hemodialysis were studied ex vivo on in vitro cultured VEC. In separate experiments, NAC $1 \mathrm{mmol} / \mathrm{L}$ or SUL $0.5 \mathrm{LRU} / \mathrm{mL}$ were added to uremic serum samples. Both changes in the gene expression and secretory activity of VEC were studied. Results: Uremic serum increased the expression of the following genes: IL6 +97\%, $p<0.002$; VEGF $+28 \%, p<$ $0.002 ; \mathrm{VWF}+47 \%, p<0.002$; PECAM +76\%, $p<0.002$; ICAM $-1+275 \%, p<0.002 ; \mathrm{t}-\mathrm{PA}+96 \%$, $p<0.002$. Changes in gene expression were reflected by the increased secretory activity of VEC treated with the uremic serum. Exposure of VEC to uremic serum supplemented with NAC or SUL resulted in weaker stimulation of the studied genes' expression. Also, secretion of the studied solutes, with the exception of ICAM-1, was reduced in the presence of NAC: IL6 -34\%, $p<0.01$; VEGF $-40 \%, p<0.005$; VWF $-25 \%, p<0.001$; t-PA $-47 \%, p<0.01$, and MMP9 $-37 \%$, $p<0.001$. SUL reduced the uremic serum-induced secretion of all solutes: IL6 $-24 \%, p<0.05$; ICAM-1 -43\%, $p<0.01$; VEGF -38\%, $p<0.01$; VWF $-23 \%, p<0.01$; t-PA $-49 \%, p<0.01$, and MMP9 $-25 \%, p<0.05$. Conclusions: Uremic serum induces prothrombotic changes in VEC, which may cause a predisposition to thrombotic disorders in patients with renal failure. NAC and SUL reduce the effects of the uremic serum in VEC, which suggests their potential therapeutic application in uremic patients.




\section{Kidney \\ Blood Pressure \\ Research}

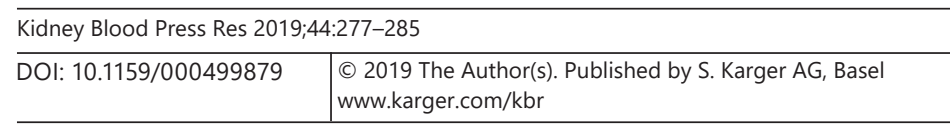

Sosinska-Zawierucha et al.: NAC and Sulodexide Modify Effect of Uremia on Venous Endothelium

\section{Introduction}

Paradoxically, in patients with end stage renal failure, despite the increased risk of bleeding, thrombotic disorders are common, which may result in life-threatening situations such as pulmonary artery embolism [1]. The incidence of spontaneous venous thrombosis and pulmonary embolism increases proportionally to the progression of the renal failure [2]. In patients with end stage renal failure, there is also increased risk of thrombotic complications after endovascular procedures such as angioplasty [3]. The occurrence of deep vein thrombosis is higher in renal patients than in patients with other diseases, and the risk of such pathology is linked with activation of procoagulant markers, decreased anticoagulants, or enhanced platelet activation [4].

There are several potential mechanisms leading to thrombotic disorders in renal patients, such as hemodialysis-induced platelet aggregation [5], increased blood level of procoagulant factors [6] or uremic toxins [7]. Abnormal endothelial function can also contribute to the development of thrombotic events due to a damaged glycocalyx, which is a natural antithrombotic structure on the surface of these cells [8], increased synthesis of tissue factor [9] or adhesion molecules [10]. Atherosclerotic changes in the arterial system can also accelerate the formation of intravascular thrombi due to the interaction between the blood clotting factors, platelets, and atherosclerotic plaques [11].

Treatment of thrombotic disorders in renal patients is difficult due to the fact that uremia at the same time may impair the blood coagulation system. Furthermore, due to renal failure, the metabolism and excretion of drugs is altered. Low molecular weight heparin preparations, which are commonly used in the prevention of thromboembolic disease, may cause bleeding complications in renal patients [12]. Intravascular thrombosis in renal patients is induced through various mechanisms, and therefore, we should look for the most effective and at the same time safe treatment of that disorder. We present data from a study in which we evaluated the effect of uremic serum on function of venous endothelial cells (VEC) and tested two different substances, $\mathrm{N}$-acetylcysteine and sulodexide, which can potentially modulate uremia-induced dysfunction of the endothelium.

\section{Material and Methods}

Experiments were performed on VEC in in vitro culture which were exposed to serum obtained from patients with end stage renal failure. The study was approved by the Ethical Committee at Poznan University of Medical Sciences. All 12 patients participating in the study gave their informed consent. Blood samples were collected before the start of the hemodialysis session. The mean age of the patients was $54.4 \pm 5.2$ years, the duration of renal replacement therapy was $41 \pm 11$ months, and GFR was $7.4 \pm 3.1 \mathrm{~mL} / \mathrm{min}$. Diabetics, patients with acute or chronic inflammatory diseases or peripheral vein insufficiency were excluded from the study. Collected serum samples were stored at $-86^{\circ} \mathrm{C}$ until they were used during the experiments.

The study was performed on in vitro cultured human umbilical vein endothelial cells (Life Technologies Corporation, Carlsbad, USA). Cells were cultured in medium M200 supplemented with $2 \%$ fetal bovine serum, heparin $10 \mu \mathrm{g} / \mathrm{mL}$, hydrocortisone $1 \mu \mathrm{g} / \mathrm{mL}$, basic fibroblast growth factor $3 \mathrm{ng} / \mathrm{mL}$, and human epidermal growth factor $10 \mathrm{ng} / \mathrm{mL}$. Experiments were performed on cell monolayers. Cells were exposed during $24 \mathrm{~h}$ to the studied media, and at the end of the incubation, the expression of the studied genes and the secretory activity of the cells were studied. The following experimental groups were studied:

1 Medium supplemented with $20 \%$ control serum 
Table 1. Characteristics of primers used in the study

\begin{tabular}{lllll}
\hline Gene & Name & $\begin{array}{l}\text { Gene } \\
\text { ID }\end{array}$ & $\begin{array}{l}\text { Amplicon } \\
\text { length, bp }\end{array}$ & Primer sequence $\left(5^{\prime} \rightarrow 3^{\prime}\right)$ \\
\hline ACT $\beta$ & Actin $\beta$ & 60 & 132 & $\begin{array}{l}\text { F:AAAGACCTGTACGCCAACAC } \\
\text { R:CTCAGGAGGAGCAATGATCTTG }\end{array}$ \\
\hline GAPDH & $\begin{array}{l}\text { Glyceraldehyde-3-phosphate } \\
\text { dehydrogenase }\end{array}$ & 2597 & 231 & $\begin{array}{l}\text { F:TTCGTCATGGGTGTGAACC } \\
\text { R:GATGATGTTCTGGAGAGCCC }\end{array}$ \\
\hline HPRT & $\begin{array}{l}\text { Hypoxanthine phosphoribosyl } \\
\text { transferase 1 }\end{array}$ & 3251 & 192 & $\begin{array}{l}\text { F:TGCTCGAGATGTGATGAAGG } \\
\text { R:TCCCCTGTTGACTGGTCATT }\end{array}$ \\
\hline IL6 & Interleukin 6 & 3569 & 264 & $\begin{array}{l}\text { F:ATGAACTCCTTCTCCACAAGC } \\
\text { R:GTTTTCTGCCAGTGCCTCTTTG }\end{array}$ \\
\hline vWF & Von Willebrand factor & 7450 & 232 & $\begin{array}{l}\text { F:CCAGATTTGCCACTGTGATG } \\
\text { R:AAAGGCCTTCAGCACTTCAA }\end{array}$ \\
\hline MMP9 & Matrix metallopeptidase 9 & 4318 & 219 & $\begin{array}{l}\text { F:TCTATGGTCCTCGCCCTGAA } \\
\text { R:CATCGTCCACCGGACTCAAA }\end{array}$ \\
\hline VEGFA & Vascular endothelial growth & 7422 & 123 & $\begin{array}{l}\text { F:CTTGCCTTGCTGCTCTACCT } \\
\text { R:GCAGTAGCTGCGCTGATAGA }\end{array}$ \\
\hline PECAM1 & $\begin{array}{l}\text { Platelet and endothelial cell } \\
\text { adhesion molecule 1 }\end{array}$ & 5175 & 222 & $\begin{array}{l}\text { F:TCAAATAGCCTGCTGGGGAG } \\
\text { R:CTGGCCTGACTCAGTCTTTGA }\end{array}$ \\
\hline tPA & Tissue plasminogen activator & 5327 & 267 & $\begin{array}{l}\text { F:ACCGGGTGGAATATTGCTGG } \\
\text { R:TGTTCCAGTTGGTGCACTCG }\end{array}$ \\
\hline ICAM-1 & $\begin{array}{l}\text { Intercellular adhesion } \\
\text { molecule 1 }\end{array}$ & 3383 & 234 & $\begin{array}{l}\text { F:CGCTGAGCTCCTCTGCTAC } \\
\text { R:AATCGCTGTCTCTAGCCCCT }\end{array}$ \\
\hline & & & &
\end{tabular}

2 Medium supplemented with 20\% uremic serum

3 Medium supplemented with 20\% uremic serum and $\mathrm{N}$-acetylcysteine $1 \mathrm{mmol} / \mathrm{L}$

4 Medium supplemented with $20 \%$ uremic serum and sulodexide $0.5 \mathrm{LRU} / \mathrm{mL}$

\section{Analysis of Gene Expression}

Experiments were performed on VEC monolayers in 6-well plates. After $24 \mathrm{~h}$ incubation of the studied media, gene expression was studied in the cells. Gene expression analysis was calculated using the quantitative real-time PCR technique. Total RNAs from VEC were isolated using the ReliaPrep ${ }^{\mathrm{TM}}$ RNA Cell Miniprep System (Promega, USA) according to the manufacturer's protocol. After the treatment of RNA samples with DNase I (Ambion, USA), RNA concentrations were measured with a NanoDrop UV-Vis spectrophotometer (NanoDrop, Thermo Scientific, USA). The quality of the obtained RNA samples was determined by the PrimePCR RNA Quality SYBR Green Assay (Bio-Rad, USA).

From each sample, one microgram of total RNA was reverse-transcribed to cDNA using random primers from the iScript cDNA Synthesis Kit (Bio-Rad, USA). The relative expression levels of 7 genes of interest, Interleukin-6 (IL6), Von Willebrand Factor (vWF), Matrix Metallopeptidase 9 (MMP9), Vascular Endothelial Growth Factor A (VEGFA), Platelet and Endothelial Cell Adhesion Molecule 1 (PECAM1), Tissue Plasminogen Activator (t-PA), and Intercellular Adhesion Molecule 1 (ICAM-1), were analyzed in triplicate using SsoAdvanced ${ }^{\mathrm{TM}}$ Universal SYBR ${ }^{\circledR}$ Green Supermix (Bio-Rad, USA) and normalized to levels of internal housekeeping genes Actin $\beta$ (ACT $\beta$ ), Glyceraldehyde-3-Phosphate Dehydrogenase (GAPDH), and 


\section{Kidney \\ Blood Pressure \\ Research}

Fig. 1. Expression of the studied genes in VEC after exposure to the uremic serum. Results are presented as the relative change versus control serum.

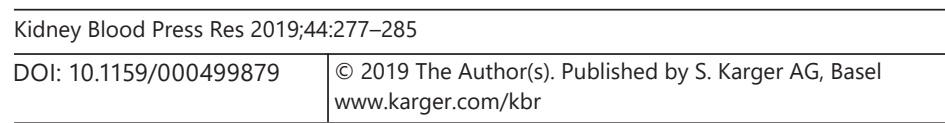

Sosinska-Zawierucha et al.: NAC and Sulodexide Modify Effect of Uremia on Venous Endothelium

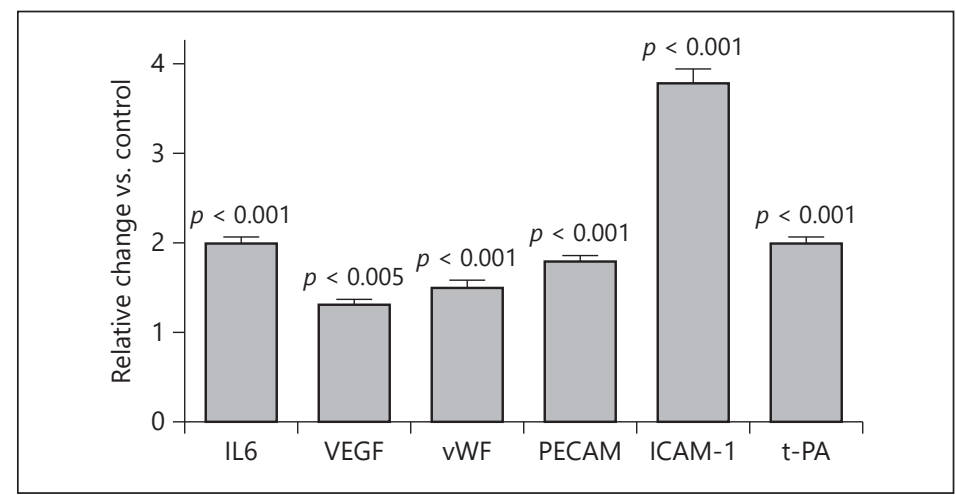

Hypoxanthine-Guanine Phosphoribosyltransferase 1 (HRPT1). Sequence-specific primers of 7 genes of interest were designed using Primer3Plus [13]. The list of primers is presented in Table 1.

The relative quantification of the expression of the selected genes was performed using Bio-Rad CFX96 equipment (Bio-Rad, USA). The reaction thermal conditions were $95^{\circ} \mathrm{C}$ for $30 \mathrm{~s}$ (polymerase activation) followed by 40 cycles of $95^{\circ} \mathrm{C}$ for $15 \mathrm{~s}$ (denaturation) and $60^{\circ} \mathrm{C}$ for $1 \mathrm{~min}$ (annealing and extension). The verification of the specificity of amplicons was performed by melting curve analysis. Relative quantification of gene expression was calculated for each sample by the $2^{-\Delta \Delta C T}$ method [14].

Evaluation of the Secretory Activity of VEC

Experiments were performed on the VEC monolayers in 24-well culture plates. Cells were exposed during $24 \mathrm{~h}$ to the studied media and then, during the following $24 \mathrm{~h}$, to serum free medium for evaluation of their secretory activity. At the end of the incubation, medium from the wells was collected for measurement of the studied solutes:

1 IL6 (Elisa kit, Sigma-Aldrich, St. Louis, MO, USA)

2 ICAM-1 (Elisa kit, Sigma-Aldrich, St. Louis, MO, USA)

3 VEGF (Elisa kit, R\&D, Minneapolis, MN, USA)

4 vWF (Elisa kit, Sigma-Aldrich, St. Louis, MO, USA)

5 t-PA (Elisa kit, R\&D, Minneapolis, MN, USA)

6 MMP9 (Elisa kit, R\&D, Minneapolis, MN, USA)

Cells in the wells were lysed with $0.1 \mathrm{~N} \mathrm{NaOH}$, and concentration of protein in the lysate was measured with the Quick-Start Bradford Protein Assay (Bio-Rad Laboratories, Hercules, CA, USA). Secretory activity of the cells was expressed per amount of the cellular protein.

\section{Statistical Analysis}

Results are presented as mean + SD. Statistical analysis was performed with the Wilcoxon test or with one-way analysis of variance with the post hoc Newman Keuls test. A $p$ value less than 0.05 was considered statistically significant.

\section{Results}

In vitro exposure of VEC to uremic serum caused increased expression of the studied genes as compared to cells treated with control serum: IL6 +97\%, $p<0.002$; VEGF $+28 \%, p<$ $0.002 ; \mathrm{vWF}+47 \%, p<0.002 ;$ PECAM $+76 \%, p<0.002 ;$ ICAM- $1+275 \%, p<0.002 ; \mathrm{t}-\mathrm{PA}+96 \%$, $p<0.002$ (Fig. 1). Changes in gene expression were reflected by increased secretory activity 
Fig. 2. Expression of the studied genes in VEC exposed to uremic serum and NAC (grey bars) or to uremic serum and sulodexide (white bars), presented as the relative change versus expression in the presence of uremic serum alone. Statistical difference between NAC and sulodexide group is shown $\left({ }^{*} p<0.001\right)$.

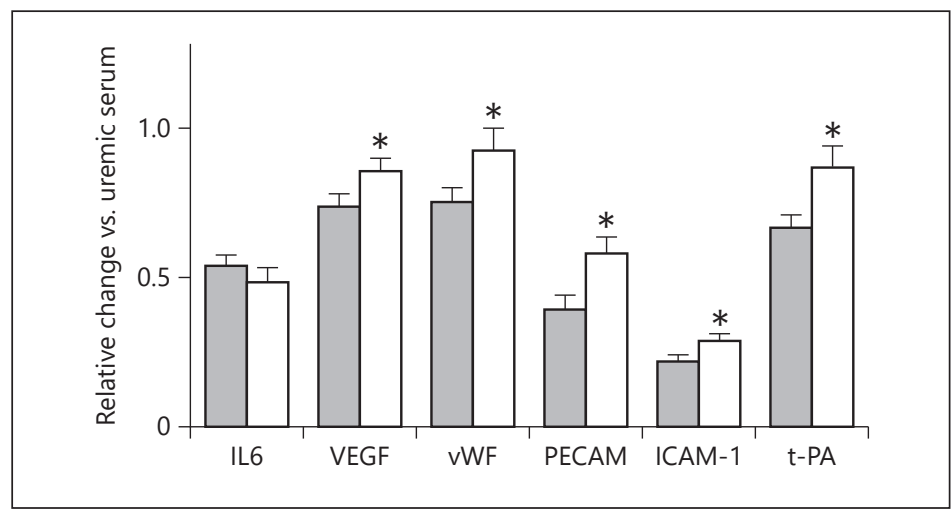

Table 2. Mean values \pm SD of secreted molecules from VEC exposed to control or uremic serum

\begin{tabular}{lccl}
\hline Secreted molecule & Control serum & Uremic serum & $p$ \\
\hline IL6, pg/mg cell protein & $155 \pm 33$ & $193 \pm 34$ & $<0.01$ \\
ICAM-1, pg/mg cell protein & $462 \pm 77$ & $1,170 \pm 292$ & $<0.001$ \\
VEGF, pg/mg cell protein & $70 \pm 23$ & $104 \pm 27$ & $<0.005$ \\
vWF, pg/mg cell protein & $281 \pm 118$ & $405 \pm 78$ & $<0.01$ \\
t-PA, pg/mg cell protein & $279 \pm 80$ & $443 \pm 126$ & $<0.005$ \\
MMP9, pg/mg cell protein & $226 \pm 66$ & $2,147 \pm 424$ & $<0.001$ \\
\hline
\end{tabular}

of VEC treated with the uremic serum: IL6 +25\%, $p<0.01$; ICAM-1 +153\%, $p<0.001$; VEGF $+49 \%, p<0.005 ; \mathrm{vWF}+44 \%, p<0.01 ; \mathrm{t}-\mathrm{PA}+59 \%, p<0.005$, and MMP9 +861\%, $p<0.001$ (Table 2).

Exposure of VEC to uremic serum supplemented with $\mathrm{N}$-acetylcysteine $1 \mathrm{mmol} / \mathrm{L}$ or sulodexide $0.5 \mathrm{LRU} / \mathrm{mL}$ resulted in weaker stimulation of the studied gene expression (Fig. 2). Also, secretion of the studied solutes, with the exception of ICAM-1, was reduced in the presence of N-acetylcysteine $1 \mathrm{mmol} / \mathrm{L}$ : IL6 -34\%, $p<0.01$; VEGF $-40 \%, p<0.005$; vWF $-25 \%, p<0.001$; t-PA $-47 \%, p<0.01$, and MMP9 $-37 \%, p<0.001$. Sulodexide $0.5 \mathrm{LRU} / \mathrm{mL}$ reduced the uremic serum-induced secretion of all solutes: IL6 -24\%, $p<0.05$; ICAM-1 $-43 \%$, $p<0.01$; VEGF $-38 \%, p<0.01$; vWF $-23 \%, p<0.01$; t-PA $-49 \%, p<0.01$, and MMP9 $-25 \%$, $p<0.05$ (Fig. 3, 4).

\section{Discussion}

The presented results confirm that VEC, after exposure to uremic serum, acquire the prothrombotic genotype and phenotype. Previously, Chitalia and co-workers [15] demonstrated that uremic serum augmented the expression of tissue factor in vascular smooth muscle cells, which resulted in increased thrombotic risk. The increased expression and secretory activity of VEC observed in our study may enhance the risk of thrombotic disorders due to the high levels of IL6 [16], ICAM-1 [17], vWF [18], and MMP9 [19]. Our results suggest that abnormal function of the VEC during uremia plays an important role in the development of thrombotic disorders. At the same time, in end stage renal failure patients, there are other risk factors typical for that population leading to thrombosis, such as bioincompatibility of 
Fig. 3. Secretion of IL6 (a), ICAM1 (b), and VEGF (c) from VEC treated with uremic serum or uremic serum supplemented with NAC $1 \mathrm{mmol} / \mathrm{L}$ or sulodexide (SUL) 0.5 LRU/mL. Statistical significance is shown versus effect of uremic serum alone.

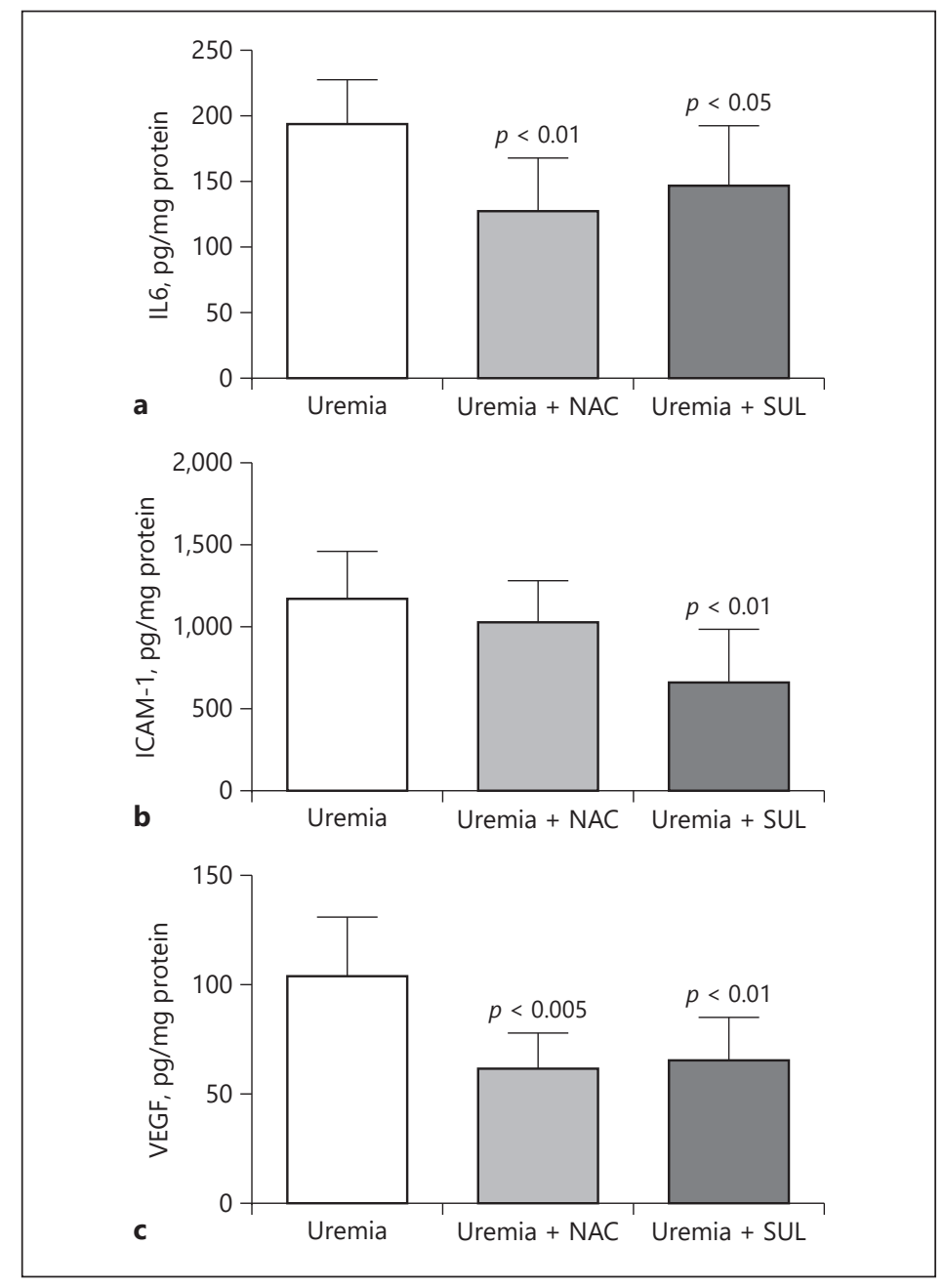

hemodialysis membranes or administration of recombinant erythropoietin [1]. Therefore, there is a need for the effective treatment of thrombotic disorders in that group of patients, which, however, is not easy because of the multiple disorders caused by renal failure which can interfere with the applied therapy [20]. The results of our study suggest that both $\mathrm{N}$-acetylcysteine and sulodexide significantly reverse the prothrombotic state of VEC, which may result in the reduction of thrombotic disorders in uremic patients.

$\mathrm{N}$-acetylcysteine efficiency in the treatment of intravascular thrombi has been shown before. Martinez de Lizarrondo and co-workers [21] demonstrated that intravenously administered $\mathrm{N}$-acetylcysteine has a thrombolytic effect on arterial thrombi, and its action depends on reducing the bisulfide bridges in large vWF multimers, which results in platelet disaggregation. Our results show that N-acetylcysteine reduces the synthesis of vWF in VEC (Fig. 4), which enhances its antithrombotic effect. In another study, the inhibiting action of N-acetylcysteine on platelet activation was found, which also results in the antithrombotic effect of that drug [22]. Our results show that $\mathrm{N}$-acetylcysteine reduces the expression of PECAM1 in endothelial cells (Fig. 2), which may also decrease the interaction of platelets with the endothelium and the formation of thrombi. The results of our study demonstrating the inhibiting effect of N-acetylcysteine on uremic serum-induced synthesis in the EVC of IL6, MMP9, and vWF show the complexity of the antithrombotic effect of $\mathrm{N}$-acetylcysteine on the level of the venous endothelium. The validity of $\mathrm{N}$-acetylcysteine as an antithrombotic agent was also 


\section{Research}

Sosinska-Zawierucha et al.: NAC and Sulodexide Modify Effect of Uremia on Venous Endothelium

Fig. 4. Secretion of vWF (a), t-PA (b), and MMP9 (c) from VEC treated with uremic serum or uremic serum supplemented with NAC $1 \mathrm{mmol} / \mathrm{L}$ or sulodexide (SUL) 0.5 LRU/mL. Statistical significance is shown versus effect of uremic serum alone.

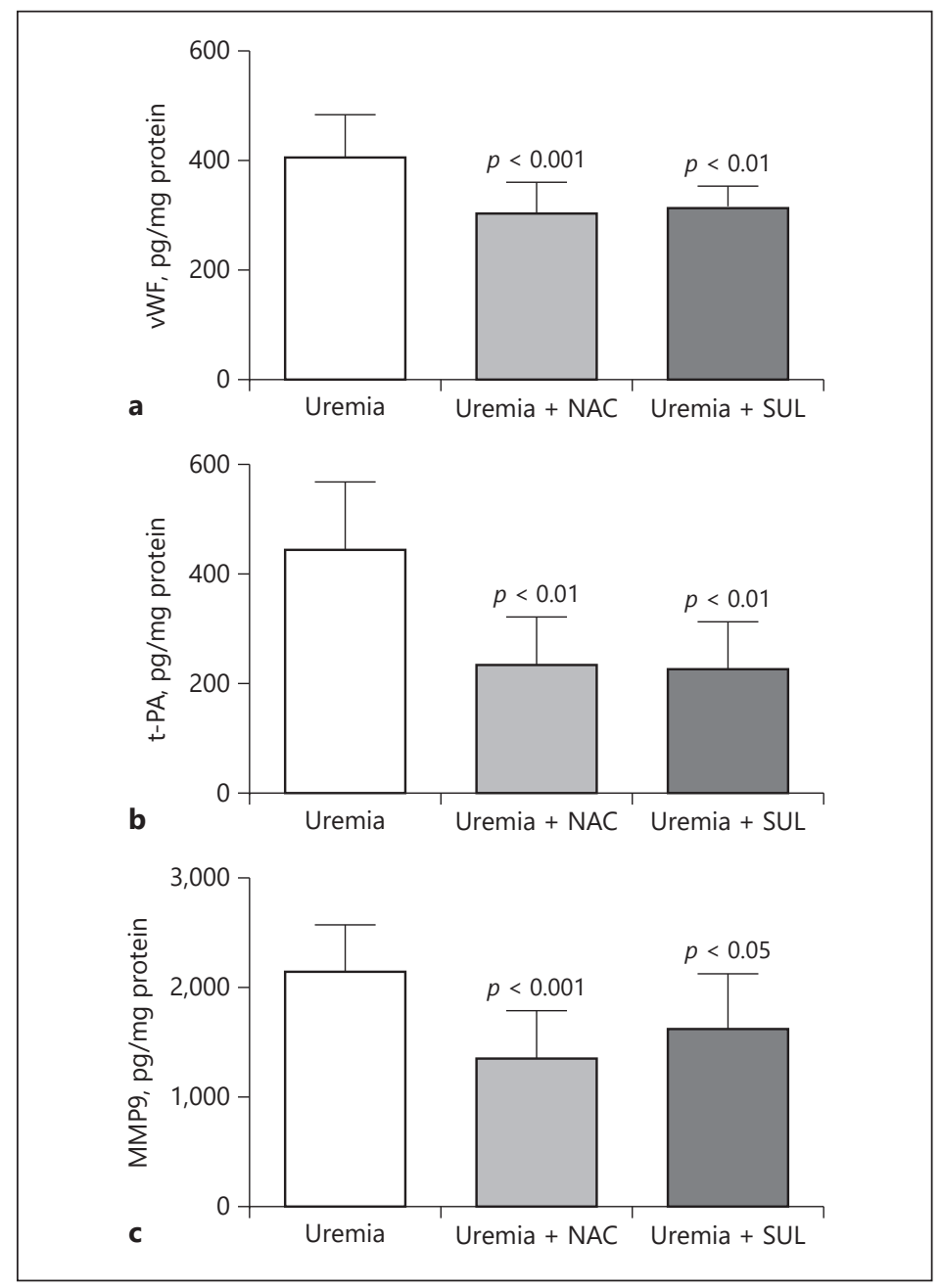

confirmed in a patient with multiple venous and arterial thrombotic events which were resistant to conventional therapy [23]. However, that was an observation made in one patient, and further studies are required to confirm the validity of $\mathrm{N}$-acetylcysteine in the treatment of thrombotic disorders in uremic patients.

Sulodexide, as with $\mathrm{N}$-acetylcysteine, reduced the prothrombotic changes in VEC exposed to uremic serum in our experiments. Both gene expression and secretion of IL6, ICAM-1, vWF, and MMP9 were reduced, and all these effects in in vivo conditions may translate into a lower risk of intravascular thrombosis (Fig. 2-4). Sulodexide's efficiency in the prevention of deep vein thrombosis is well known and was confirmed in many clinical studies [24]. In our previous studies, we demonstrated that the antithrombotic action of sulodexide is linked with its antioxidant and anti-inflammatory effects on the level of the venous endothelium $[25,26]$. The results of the present study show that sulodexide may also be effective in the prevention of thromboembolic disorders in a group of patients with end stage renal failure. An important disorder which can increase the risk of intravascular thrombosis is damage to the glycocalyx, observed in patients on renal replacement therapy [8]. Dysfunction of the glycocalyx leads to many disorders, such as increased capillary permeability and interaction of the endothelium with leukocytes and platelets, which predisposes patients to intravascular thrombosis [27]. Chronic administration of sulodexide, which is a mixture of glycosaminoglycans present in the glycocalyx, results in the rebuilding of that structure [28]. Normal structure of the glyco- 


\section{Kidney \\ Blood Pressure Research}

\begin{tabular}{l|l}
\hline Kidney Blood Press Res 2019;44:277-285 \\
\hline DOI: 10.1159/000499879 & $\begin{array}{l}\text { @ 2019 The Author(s). Published by S. Karger AG, Basel } \\
\text { www.karger.com/kbr }\end{array}$ \\
\hline
\end{tabular}

Sosinska-Zawierucha et al.: NAC and Sulodexide Modify Effect of Uremia on Venous Endothelium

calyx together with reduced expression of PECAM and ICAM-1 in the presence of sulodexide observed in our experiments can significantly reduce interactions between the vascular endothelium, leukocytes, and platelets, which will result in lower risk of intravascular thrombosis.

In conclusion, we found that in the uremic milieu, VEC acquire the prothrombotic genotype and phenotype, which may predispose patients to thromboembolic disorders in end stage renal failure. Both $\mathrm{N}$-acetylcysteine and sulodexide reduce the uremic seruminduced changes in the endothelial cells, which must result in reduced risk of thrombosis in that group of patients. The structure of both tested substances is totally different, and one can assume that these substances can induce the additive antithrombotic effect in uremic patients. Further studies are required to confirm this hypothesis.

\section{Acknowledgements}

Research was supported by the following grants from the National Science Center Poland: OPUS 2017/27/B/NZ4/01675; IUVENTUS Plus 0733/IP1/2016/74.

\section{Disclosure Statement}

The authors do not disclose any conflict of interest.

\section{References}

1 Casserly LF, Dember LM. Thrombosis in end-stage renal disease. Semin Dial. 2003 May-Jun;16(3):245-56.

2 Kumar G, Sakhuja A, Taneja A, Majumdar T, Patel J, Whittle J, et al.; Milwaukee Initiative in Critical Care Outcomes Research (MICCOR) Group of Investigators. Pulmonary embolism in patients with CKD and ESRD. Clin J Am Soc Nephrol. 2012 Oct;7(10):1584-90.

3 Iakovou I, Schmidt T, Bonizzoni E, Ge L, Sangiorgi GM, Stankovic G, et al. Incidence, predictors, and outcome of thrombosis after successful implantation of drug-eluting stents. JAMA. 2005 May;293(17):2126-30.

4 Wattanakit K, Cushman M. Chronic kidney disease and venous thromboembolism: epidemiology and mechanisms. Curr Opin Pulm Med. 2009 Sep;15(5):408-12.

5 Viener A, Aviram M, Better OS, Brook JG. Enhanced in vitro platelet aggregation in hemodialysis patients. Nephron. 1986;43(2):139-43.

6 Tomura S, Nakamura Y, Doi M, Ando R, Ida T, Chida Y, et al. Fibrinogen, coagulation factor VII, tissue plasminogen activator, plasminogen activator inhibitor-1, and lipid as cardiovascular risk factors in chronic hemodialysis and continuous ambulatory peritoneal dialysis patients. Am J Kidney Dis. 1996 Jun;27(6):848-54.

7 Shashar M, Francis J, Chitalia V. Thrombosis in the uremic milieu-emerging role of "thrombolome". Semin Dial. 2015 Mar-Apr;28(2):198-205.

8 Vlahu CA, Lemkes BA, Struijk DG, Koopman MG, Krediet RT, Vink H. Damage of the endothelial glycocalyx in dialysis patients. J Am Soc Nephrol. 2012 Nov;23(11):1900-8.

9 Gondouin B, Cerini C, Dou L, Sallée M, Duval-Sabatier A, Pletinck A, et al. Indolic uremic solutes increase tissue factor production in endothelial cells by the aryl hydrocarbon receptor pathway. Kidney Int. 2013 Oct;84(4): 733-44.

10 Serradell M, Díaz-Ricart M, Cases A, Zurbano MJ, López-Pedret J, Arranz O, et al. Uremic medium causes expression, redistribution and shedding of adhesion molecules in cultured endothelial cells. Haematologica. 2002 Oct;87(10):1053-61.

11 Rauch U, Osende JI, Fuster V, Badimon JJ, Fayad Z, Chesebro JH. Thrombus formation on atherosclerotic plaques: pathogenesis and clinical consequences. Ann Intern Med. 2001 Feb;134(3):224-38.

12 Gerlach AT, Pickworth KK, Seth SK, Tanna SB, Barnes JF. Enoxaparin and bleeding complications: a review in patients with and without renal insufficiency. Pharmacotherapy. 2000 Jul;20(7):771-5.

13 Untergasser A, Nijveen H, Rao X, Bisseling T, Geurts R, Leunissen JA. Primer3Plus, an enhanced web interface to Primer3, Nucleic Acids Res. 2007;35(Web Server issue):W71-4

14 Livak KJ, Schmittgen TD. Analysis of relative gene expression data using real-time quantitative PCR and the 2(-Delta Delta C(T)) Method. Methods. 2001 Dec;25(4):402-8. 
15 Chitalia VC, Shivanna S, Martorell J, Balcells M, Bosch I, Kolandaivelu K, et al. Uremic serum and solutes increase post-vascular interventional thrombotic risk through altered stability of smooth muscle cell tissue factor. Circulation. 2013 Jan;127(3):365-76.

16 D’Elia JA, Weinrauch LA, Gleason RE, Lipinska I, Lipinski B, Lee AT, et al. Risk factors for thromboembolic events in renal failure. Int J Cardiol. 2005 May;101(1):19-25.

17 Fadel FI, Elshamaa MF, Nabhan MM, Essam RG, Kantoush N, El Sonbaty MM, et al. Soluble adhesion molecules as markers of native arteriovenous fistula thrombosis in children on uremia. Blood Coagul Fibrinolysis. 2014 Oct;25(7):675-82.

18 Sagripanti A, Cupisti A, Baicchi U, Ferdeghini M, Morelli E, Barsotti G. Plasma parameters of the prothrombotic state in chronic uremia. Nephron. 1993;63(3):273-8.

19 Gheissari A, Meamar R, Abedini A, Roomizadeh P, Shafiei M, Samaninobandegani Z, et al. Association of Matrix Metalloproteinase-2 and Matrix Metalloproteinase-9 With Endothelial Dysfunction, Cardiovascular Disease Risk Factors and thrombotic events in Children With End-stage Renal Disease. Iran J Kidney Dis. 2018 May; 12(3):169-77.

20 Long B, Koyfman A, Lee CM. Emergency medicine evaluation and management of the end stage renal disease patient. Am J Emerg Med. 2017 Dec;35(12):1946-55.

21 Martinez de Lizarrondo S, Gakuba C, Herbig BA, Repessé Y, Ali C, Denis CV, et al. Potent Thrombolytic Effect of N-Acetylcysteine on Arterial Thrombi. Circulation. 2017 Aug;136(7):646-60.

22 Wang B, Yee Aw T, Stokes KY. N-acetylcysteine attenuates systemic platelet activation and cerebral vessel thrombosis in diabetes. Redox Biol. 2018 Apr;14:218-28.

23 Blanco-Vaca F, López N, Cuquet J, Mateo J. Patient presenting multiple consecutive venous and arterial thrombotic events despite intensive conventional treatment: response after normalization of plasma homocysteine and N-acetylcysteine therapy. J Intern Med. 2003 Oct;254(4):397-400.

24 Andreozzi GM, Bignamini AA, Davì G, Palareti G, Matuška J, Holý M, et al.; SURVET Study Investigators. Sulodexide for the Prevention of Recurrent Venous Thromboembolism: The Sulodexide in Secondary Prevention of Recurrent Deep Vein Thrombosis (SURVET) Study: A Multicenter, Randomized, Double-Blind, PlaceboControlled Trial. Circulation. 2015 Nov;132(20):1891-7.

25 Połubińska A, Staniszewski R, Baum E, Sumińska-Jasińska K, Bręborowicz A. Sulodexide modifies intravascular homeostasis what affects function of the endothelium. Adv Med Sci. 2013;58(2):304-10.

26 Urbanek T, Krasinski Z, Sumińska-Jasińska K, Baum E, Borej-Nowicka G, Begier-Krasińska B, et al. Sulodexide reduces the inflammatory reaction and senescence of endothelial cells in conditions involving chronic venous disease. Int Angiol. 2016 Apr;35(2):140-7.

27 Sieve I, Münster-Kühnel AK, Hilfiker-Kleiner D. Regulation and function of endothelial glycocalyx layer in vascular diseases. Vascul Pharmacol. 2018 Jan;100:26-33.

28 Li T, Liu X, Zhao Z, Ni L, Liu C. Sulodexide recovers endothelial function through reconstructing glycocalyx in the balloon-injury rat carotid artery model. Oncotarget. 2017 Aug;8(53):91350-61. 